\title{
Austro-Hungarian Volkskunde at War: Scientists on Ethnographic Mission in World War I
}

\author{
Christian Marchetti
}

Toward the middle of World War I, an Austro-Hungarian daily described the benefits of all-out war for scientific endeavor:

It is an old and well-known fact that war advances science; that it expands and deepens it. The greater the struggle for victory, the more demanding the requests made and the richer the resources given become. What in quiet times is only of value and interest to exclusive circles, prospering only barely in the confines of the study and the laboratory, is now seen as significant by a broad public and lavishly supported so that it may create for the one who destroys.

With the exception of utterly ivory-tower branches of knowledge, every discipline is now experiencing the fertilizing effects of the world war, and its exponents, even those under arms in the field, feel the duty to take full advantage of this blood-soaked opportunity. [...] Previously inaccessible areas and xenophobic peoples and tribes are explored and studied; their character is penetrated and interpreted. Antiquities are drawn, collected and listed, as are dialects, traditional costumes, mores and customs. Landscapes are surveyed, rivers sketched, and ores and geological data searched for. ${ }^{1}$

The "previously inaccessible areas" in question were the Balkans. AustroHungarian imperial forces had occupied the peninsula's western reaches in early 1916. War dismantled various obstacles that had hitherto "averted the scientific current and deflected it into the African colonies of the Great Powers and the owner-less Arctic and Antarctic." ${ }^{2}$ They included absent lines of com-

1 "Die Balkanforschung," Pester Lloyd, May 12, 1917, 6-7.

2 Ibid. The article quoted was one in a series intended to secure a piece of the action for the Balkans Institute in Sarajevo mentioned below. Its director Carl Patsch obviously felt neglected by the war-driven advancement of science. 
munication, frequent borders, and the distrust or outright malevolence of its inhabitants and authorities.

Among the disciplines benefiting from the scientific boom created by the Great War was the German-speaking Volkskunde of the Austro-Hungarian Empire. In the multiethnic dual monarchy, cultural branches of anthropology followed an idiosyncratic Sonderweg. While Germany cultivated a structural division between an inward-looking Volkskunde that investigated and invented the folk culture of its own nation and an outward-looking Völkerkunde that explored the "primitive" cultures of colonial Others, such dichotomies in Austria-Hungary were as blurred and contested as the disciplines themselves. World War I became a milestone on their path toward institutionalization and professionalization. Beyond its adverse effect on the multiethnic political realm, the war mobilized all sectors of society and the state, offering the young discipline a probationary field that it entered willingly.

This field was represented geographically by the occupied Balkan territories. From a western European perspective, the southeastern peninsula was perceived as a transitional zone between the European Self and the Oriental Other. Its in-between position, symbolized in the image of a bridge, construes the post-Ottoman Balkans as the West's "Other within," an inextricable part of Europe, but an incomplete Self. ${ }^{3}$ The perception extends to the Balkans' political (dis-)organization. While the classic oriental Other ${ }^{4}$ could be subjected to colonial discourse and ascriptions of oriental despotisms, the Balkans were the area where the putative ideal of European statehood, the homogeneous nation-state, was seen as perverted by hypertrophy. "Balkanization," a pejorative term for the fragmentation of former multiethnic imperial dominions into presumably nonviable and aggressive mini-nation-states, emerged in Western political discourse around the time of the Balkan Wars of 1912-1913. ${ }^{5}$

The Austro-Hungarian Empire was a special case. It bordered directly on the Balkans, even including parts of it. Ethnic heterogeneity and nationalist quarrels were features the two entities shared. The emergence of small nation-states in the area posed a direct threat to the Empire by providing some citizens with national affiliations beyond the dual monarchy. Hence, its attitude toward both the Balkans and the Orient differed from that of other European nation-states and imperial colonial powers: The Balkans were historically the space where the Empire's own mission became manifest. Turkish armies based there had threatened Christian Europe for hundreds of years, and their defeat at the walls of Vienna marked the advent of Austria's imperial mission and golden age.

3 Maria Todorova, Imagining the Balkans (New York: Oxford University Press, 1997), 15-17.

4 Edward W. Said, Orientalism (London: Penguin Books, 2003).

5 Todorova, Imagining the Balkans, 19. 
The cultural memory of military conflict with the Ottoman Empire in early modern times and the experiences gathered during political expansion into the regions of former Ottoman colonial rule in Europe nurtured an idiosyncratic "frontier Orientalism." This perceptual pattern extended from folklore to the high arts and science, addressing male violence in nearby "Oriental" cultures and symbolically separating "good" Balkan Muslims from "bad." As a political and cultural orientation, it offered a more diversified pattern of perspectives than the classic, colonialist model of Orientalism. ${ }^{6}$

Against this background, it is the purpose of this chapter to elaborate on the wartime experience of Austrian Volkskunde. While prewar research in the western Balkans was subject to a "heroic" paradigm, the war had the seemingly paradoxical effect of pacifying the scientific approach. Before the war, male heroism and violence were the dominant patterns both in representations of Balkan folk culture and the self-representations of maverick researchers. Cultural anthropologists in uniform were more interested in material and domestic aspects of daily life, presenting themselves as professional scientists. Thus they were able to contribute to colonial politics during the occupation and realign themselves to novel circumstances after the defeat.

\section{Multiethnic Volkskunde}

The Habsburg Empire gave rise to a variety of ethnological approaches. ${ }^{7}$ Austrian ethnology of non-European cultures had its inception in the Department of Anthropology and Ethnography at the Imperial and Royal Natural History Museum, founded in $1876 .{ }^{8}$ Habsburg anthropology's main objects of

6 Andre Gingrich, "Liberalism in Imperial Anthropology: Notes on an Implicit Paradigm in Continental European Anthropology before World War I," Ab Imperio 8, no. 1 (2007): 231; idem, "Kulturgeschichte, Wissenschaft und Orientalismus: Zur Diskussion des 'frontier orientalism' in der Spätzeit der k.u.k. Monarchie," in Schauplatz Kultur-Zentraleuropa, Transdisziplinäre Annäherungen, ed. Johannes Feichtinger (Innsbruck: Studien Verlag, 2006), 279-288; idem, Frontier Myths of Orientalism: The Muslim World in Public and Popular Cultures of Central Europe, vol. 2, Mediterranean Ethnological Summer School, Piran/Pirano Slovenia 1996, eds. Bojan Baskar and Irena Weber (Ljubljana: University of Ljubljana, 1998), 99-127.

7 Reinhard Johler, "Das ethnische als Forschungskonzept: Die österreichische Volkskunde im europäischen Vergleich," in Ethnologia Europaea: 5. Internationaler Kongreß der Societé International d'Ethnologie et de Folklore Wien, 12.-16. September 1994, eds. Klaus Beitl and Olaf Bockhorn (Vienna: University of Vienna, 1995), 80.

8 Christian F. Feest, "The Origins of Professional Anthropology in Vienna," in Kulturwissenschaft im Vielvölkerstaat: Zur Geschichte der Ethnologie und 
attention were not to be found overseas, but within the Empire's own borders. No country on earth could match Austria-Hungary's potential for ethnological research, the art historian Alois Riegl stated in 1894, for the Empire incorporated north and south, east and west, and the primitive and the modernized, boasting examples of every stage of economic development. ${ }^{9}$ The Empire was seen as a microcosm of Europe, encompassing within its borders numerous national, religious, cultural, and "civilizational" differences.

In 1895, two departmental assistants, the Semitist Dr. Wilhelm Hein and the Indologist Dr. Michael Haberlandt, founded a society for Austrian Volkskunde, claiming the Empire as their field of research. In contrast to the assorted national Volkskunde disciplines that had emerged in imperial subcenters at the end of the nineteenth century, the Viennese scholars positioned themselves as anti-, or at least nonnational. To legitimize itself, the discipline aspired to close the gap between urban high culture and primitive rural culture by integrating the latter into the former. The promoters and protagonists of the young discipline, both aristocratic and bourgeois, shared a form of Austrian patriotism that emphasized the Empire's unity in space and time, searching for the natural, organic basis of its Volk. A common foundation was thought to underlie the Empire's observable cultural variety, which was conceived as superficial: Discrete national cultures were assumed to have been constructed politically.

A central concern in Austrian Volkskunde was folk art. The discipline aimed to support the preservation and elaboration of traditional styles and techniques. Preindustrial handicrafts were to be protected from obliteration by modern industry and developed into competitive cottage industries that would include rural people on fair economic terms, halting migration to the cities and other undesirable consequences of modernization. The Empire's cultural diversity would become a competitive asset by providing a multiplicity of production styles. Metropolitan Weltkultur with its tendency to elide diversity and nationalist particularisms with their exaggerations of difference were to be countered by the elemental aesthetics of handicrafts. Conserving the traditional division of labor along gender and ethnic lines would help secure internal social peace. ${ }^{10}$ In this context, Austrian Volkskunde positioned itself as an "internal colonial science."11

verwandter Gebiete in Österreich ca. 1780 bis 1918, ed. Britta Rupp-Eisenreich (Vienna: Böhlau, 1995), 113-131.

9 Alois Riegl, Volkskunst, Hausfleiß und Hausindustrie (Berlin: Mäander-Kunstverlag, 1978 [1894]), 77.

10 Michael Haberlandt, "Ausstellung österreichischer Hausindustrie und Volkskunst," Kunst und Kunsthandwerk 9 (1906): 24-52.

11 For a Habsburg version of internal colonialism, see Katherine Verdery, "Internal Colonialism in Austria-Hungary," Ethnic and Racial Studies 2 (1979): 378-399. 


\section{Bosnia and Herzegovina}

The Habsburg Empire had no overseas colonies, ${ }^{12}$ confining its imperial ambitions to European soil. The occupation of Bosnia and Herzegovina in 1878 has often been, and still is, interpreted as the beginning of Austro-Hungarian colonialism in the Balkans. The special place occupied by Bosnia and Herzegovina in the dual legal-political body of the dual monarchy, its distinctive role and weight in the internal balance of the Empire, and its ethnic situation drew especial attention from the monarchies' centers.

Service in Bosnia and Herzegovina was an experience shared by many German-speaking anthropological scholars and explorers. Felix von Luschan served in the Medical Corps in Bosnia and Herzegovina in 1878/79. During his deployment, he took part in excavations, pursuing anthropometric studies and collecting anthropological and ethnographic objects. ${ }^{13}$ Another wellknown exponent of non-European ethnology, Richard Thurnwald, acquired foreign field experience as a member of the Bosnian Regional Administration in 1896/97..$^{14}$ The career paths of both led to Germany; Luschan became the first professor of anthropology in Berlin. Fieldwork in Bosnia seems to have been an advantageous jumping-off point for Austro-Hungarian careers as well. The archaeologist Moritz Hoernes, cofounder of the Viennese Association for Volkskunde, was a member of the occupation forces, like Luschan. When the occupation ended, he was engaged by the Ministry of Education to travel through Bosnia and Herzegovina cataloging Roman archaeological sites. He later became the cultural attaché to the joint administration of Bosnia and Herzegovina in Vienna. ${ }^{15}$

Beyond personal experiences and interests, the Austro-Hungarian colonial experience in Bosnia and Herzegovina was significant for the discipline's early institutional development. In 1884, the Viennese Anthropological Society established its Ethnographic Commission with the stated aim "to effectively stimulate

12 It refrained from such ambitions more out of lacking chances than out of higher insight, see Walter Sauer, ed., K.u.k. kolonial: Habsburgermonarchie und europäische Herrschaft in Afrika (Vienna: Böhlau, 2002).

13 Marion Melk-Koch, "Zwei Österreicher nehmen Einfluß auf die Ethnologie in Deutschland: Felix von Luschan und Richard Thurnwald," in Rupp-Eisenreich, Kulturwissenschaft im Vielvölkerstaat, 132.

14 Ibid., 136; Angela Riedmann, "Richard Thurnwald in Bosnien 1896-1897: Koloniale Wege zur Ethnologie," (master's thesis, University of Vienna, 2005). Thurnwald contributed to the volume on Bosnia of the series "Die österreichisch-ungarische Monarchie in Wort und Bild," often referred to as the "Kronprinzenwerk."

15 Moritz Hoernes, "Die Altertumsforschung in Bosnien-Herzegovina," Globus 61 (1892): 129-132, 150-154. 
and support the study of the ethnography of the Balkan countries along with the ethnography of Austria-Hungary." 16 One of the first individuals to explore the newly acquired territory on behalf of the Commission was the classical philologist Friedrich Salomon Krauss. ${ }^{17}$ Touring Bosnia in 1884/85, he collected vast quantities of material, mainly folk songs from Bosnia's three main religious communities. Krauss stressed the arduousness of his travels, claiming he dressed in rags to avoid being robbed. He held his materials in high esteem, especially the oral tradition of the Muslim "sect," as he called it, which for him had Homeric qualities. ${ }^{18}$ Other groups' songs were inferior, but equally belligerent. ${ }^{19}$

Viennese learned societies continued to dispatch scientists on expeditions to Bosnia and Herzegovina in the early years of the twentieth century. While the anthropologists' mandate was defined methodologically, the Imperial Academy of Sciences' Balkan Commission, constituted in 1897, had a geographical focus, promoting primarily philological-ethnographic and historical-archaeological research projects. ${ }^{20}$ In 1913, the Slavicist and folklorist

16 Mitteilungen der Anthropologischen Gesellschaft in Wien 14 (1884): 6.

17 Krauss (1859-1938) was born in Pozega, Slawonia, as the son of a Germanspeaking Jewish father and a Slavic mother.

18 Krauss was referring to the "Homeric thesis" of South-Slavic folklorists like the Franciscan collector Grgo Martić, but by constraining the label "classical" to the Muslim songs he thwarted their preference for Christian folklore. See Zlatan Čolaković, "Bosnian Epics: Problems of Collecting and Editing the Main Collections," Forum Bosnae 39 (2007): 323-361.

19 On Krauss's life and work, see Raymond L. Burt, Friedrich Salomon Krauss (18591938): Selbstzeugnisse und Materialien zur Biobibliographie des Volkskundlers, Literaten und Sexualforschers mit einem Nachlassverzeichnis (Vienna: Verlag der Österreichischen Akademie der Wissenschaften, 1990). On Krauss as part of a "Jewish moment" in the history of early folklore studies and Völkerkunde in the German-language zone before and after World War I, see Gingrich, "Liberalism in Imperial Anthropology, 231-233; Bernd Jürgen Warneken, "Völkisch nicht beschränkte Volkskundler: Eine Erinnerung an die Gründungsphase des Fachs vor 100 Jahren," Zeitschrift für Volkskunde 95, no. 2 (1999): 169-196; idem, "Negative Assimilation: Der Volkskundler und Ethnologe Friedrich Salomo Krauss," in ... das Flüstern eines leisen Wehens ...: Beiträge zu Kultur und Lebenswelt europäischer Juden, ed. Freddy Raphael (Constance: UVK-Verlagsgesellschaft, 2001), 149-170; Christoph Daxelmüller, "Friedrich Salomo Krauss (Salomon Friedrich Kraus[s]) (1859-1938)," in Völkische Wissenschaft: Gestalten und Tendenzen der deutschen und österreichischen Volkskunde in der ersten Hälfte des 20. Jahrhunderts, ed. Wolfgang Jacobeit (Cologne: Böhlau, 1994), 461-476; on his traveling practices: Christian Marchetti, "Scientists with Guns: On the Ethnographic Exploration of the Balkans by Austrian-Hungarian Scientists before and during World War I," Ab Imperio 8, no. 1 (2007): 170-173.

20 Archiv Österreichische Akademie der Wissenschaften. Balkankommission, K1B1, Protokollbuch 1897-1907. 
Matthias Murko traveled to Bosnia and Herzegovina at its behest to research the current state of Muslim folk song. Just as Krauss had done, Murko investigated a population which he divided along religious lines. Nevertheless, he highlighted the commonalities among epic folk songs, observing the exchange between Catholic, Orthodox, and Muslim singers and audiences. The most significant unifying effect, Murko noted, derived from the songs' gory nature: "The old songs have to have a bloody topic [...] because gusle [the traditional instrument], puška [gun] and oružje [weapon] are inseparable terms." ${ }^{21}$ Heroism was held in high esteem, regardless of denomination.

But violent folklore was in decline, Murko observed. As the Bosnian hero, the junak who derived his heroic status from hand-to-hand combat in the border regions between Herzegovina and Montenegro, was transformed into a disciplined soldier in the rank and file of the Austro-Hungarian army, ${ }^{22}$ the folk songs became relics of a heroic past.

Murko could rely on active support from local government, municipal authorities, and village teachers and priests. ${ }^{23}$ More important was the regionally based scientific community that had crystallized around the Bosnian National Museum founded in Sarajevo in 1888. The local scholars adhered to a rather pacifistic - or pacifying - agenda with regard to the representation of different folk cultures, stressing the harmonious aspects of multiethnic urban life. ${ }^{24}$ As the infrastructure for research improved, conceptualization of the ethnographic field stabilized. The Sarajevo museum aspired to become a local center for the study of the entire region. In 1908, the curator of its archaeological collection, Carl Patsch, founded a Balkan Institute, gathering a comprehensive collection of source material and launching an ambitious series of publications on the surrounding countries under the rubric Zur Kunde der Balkanhalbinsel. ${ }^{25}$

21 Ibid., 33.

22 The Bosnian Units formed an elite troop in the Imperial and Royal Army. A unit was stationed in Vienna and deployed against rioting civilians. During the World War the "Bosniaken" gained the nimbus of loyal and fearless fighters, especially in mountain warfare against Italy. A rich and nostalgic account is given by Werner Schachinger, Die Bosniaken kommen! 1879-1918 Elitetruppe in der k.u.k. Armee (Graz: Leopold Stocker Verlag, 1994).

23 Mathias Murko, "Bericht über eine Reise zum Studium der Volksepik in Bosnien und der Herzegowina im Jahre 1913," Sitzungsberichte der Kais. Akademie der Wissenschaften in Wien 176 (1915): 4.

24 Diana Reynolds, "Kavaliere, Kostüme, Kunstgewerbe: Die Vorstellung Bosniens in Wien 1878-1900," in Habsburg postkolonial. Machtstrukturen und kollektives Gedächtnis, ed. Johannes Feichtinger (Innsbruck: Studienverlag, 2003), 243257.

25 Carl Patsch, 12 March 1913, Gemeinsames Finanzminsterium, in Angelegenheiten Bosniens und der Herzegovina, Z3064, Hofarchiv, Ministerium des Äußeren, Fach 74 “Institute ÖU 3," 16/19287. 


\section{The Ethnologist Who Would Be King}

In the early twentieth century and up to the beginning of World War I, political and scholarly "conquest" moved southward to the young state of Albania. ${ }^{26}$ This most recent successor state to the Ottoman Empire had been haunted by violent conflicts stemming both from repeated Montenegrine and Serbian incursions and a number of insurgencies with subsequent Ottoman repression. Given its location on the Strait of Otranto-the narrow gateway to the Adriatic-the conflicting strategic interests of Austria-Hungary and Italy did not always have a soothing effect, but they did create a geopolitical opportunity to attain national independence. After the first Balkan War of 1912, both larger countries promoted Albania's independence from the Ottoman Empire. However, international involvement was unable to stabilize the hand-picked regime led by the German Wilhelm Prinz zu Wied, whose reign lasted less than one hundred days. ${ }^{27}$

Ethnographic information on Albania came to Austria-Hungary via three sources: diplomats stationed in the consulates in Skutari (Shkodra), Valona (Vlorë), and Durrazzo (Durrës); ${ }^{28}$ Catholic clergy under the tutelage of the Habsburg cultural protectorate of the northern Albanian Catholics; and maverick adventurers whose goals were more or less scientific. From the point of view of Volkskunde, information from any of the three groups was liable to distinct flaws. For example, when the consul Theodor von Ippen offered Carl Patsch a manuscript on the northern Albanian town of Skutari (Shkodra), he refrained from delivering a description of the social situation of the "Muslim, Catholic, and Serbian population" in the town, because it would necessarily imply political judgments. Discussing questions of religion and nationality as Patsch had requested would not be scientific in the sense of neutral and objective; in Ippen's view, they had become highly politicized issues in the Balkans. As he was expected to submit his manuscript for inspection by the Foreign Ministry before publication, he self-censored statements that might be considered incorrect or undesirable. ${ }^{29}$ Clerical sources were more loquacious. Ippen

26 Günther Ramhardter, "Propaganda und Außenpolitik," in Die Habsburgermonarchie im System der internationalen Beziehungen, ed. Adam Wandruszka (Vienna: Verlag der Österreichischen Akademie der Wissenschaften, 1989), 496-536.

27 Richard C. Hall, The Balkan Wars 1912-1913: Prelude to the First World War (New York: Taylor \& Francis Ltd., 2002).

28 Even during the military occupation and administration of Albanian territory, the k.u.k. officials never used the Albanian toponyms as was planned, but used the Italian versions and, at most, added the Albanian place names in brackets. This text does the same.

29 Theodor Ippen to Carl Patch wegen Veröffentlichung "Skutari," 12 July 1907, Bay HstA, Südost-Institut, Nachlass Carl Patsch, 287. 
himself drew heavily on the accounts of two Catholic missionaries for his contribution on Albanian common law to an anthology edited by his superior, Ludwig von Thalloczy. ${ }^{30}$ But while some clerical ethnography could capitalize on long and close contact between foreign-born authors and natives, others did not meet editors' requirements. When the Croatian missionary Fra Lovro Mihačević offered Carl Patsch an article on his journeys through Albania, he was turned down. The Hungarian nobleman Franz Baron Nopcsa, ${ }^{31}$ who had arranged the contact, himself admitted that the manuscript was only partially up to standard and that the author was neither willing nor able to revise it. ${ }^{32}$

During the Balkan wars of 1912-1913, public and scientific interest in Albania was especially strong. Albania was considered a living museum of European origins. It offered uncharted landscapes and untapped resources for scholarly exploration, including the archaeological heritage of the Roman Empire and the pre-Roman Illyrian civilization. Its people, especially those in the mountainous north, were regarded as inhabiting premodern tribal social structures, with an apparently primitive material culture and an authentic common law of blood revenge and honor codes. Armed violence and war were held to be endemic. Primitivism and belligerence were the two dominant topoi in representations of Albanian culture: No image of a tribesman was complete without his gun.

Nopcsa was the imperial and royal realm's most dazzling specimen of the ethnographic maverick to visit prewar and wartime Albania. Already a recognized palaeontologist and geographer, Nopcsa found his ethnological interests sparked by his Albanian travels. With Carl Steinmetz, a teacher at the technical school in Sarajevo, he filled a good part of Carl Patsch's series with accounts of northern Albania. ${ }^{33}$ In late 1912, he delivered a public lecture on

30 Theodor Ippen, "Das Gewohnheitsrecht der Hochländer in Albanien," in Illyrisch-Albanische Forschungen, ed. Ludwig von Thalloczy (Munich: Duncker \& Humblot, 1916), 389-435.

31 Ferenz Baron Nopcsa von Felsöszla (1877-1933), born in Deva, Transylvania, to a long line of Hungarian aristocrats. His uncle held high positions at the Emperor's court. See Gert Robel, Franz Baron Nopcsa und Albanien: Ein Beitrag zu Nopcsas Biografie (Wiesbaden: O. Harrassowitz, 1966). For an insight into Nopcsa's personality, see Franz Baron Nopcsa, Reisen in den Balkan:Die Lebenserinnerungen des Franz Baron Nopcsa, ed. Robert Elsie (Peja: Dukagjini, 2001).

32 Franz Nopcsa to Patsch, 21 February, 1909, Bay HstA, Südost-Institut Nachlass Carl Patsch, 390. This correspondence is particularly interesting, because the manuscript nevertheless reached a surprising level of distribution during the war.

33 See in the series subdivision "Travels and Observations": Karl Steinmetz, Eine Reise durch die Hochländergaue Oberalbaniens (Vienna: Hartleben's Verlag, 1904); idem, Ein Vorstoss in die Nordalbanischen Alpen (Vienna: Hartleben's Verlag, 1905); idem, Von der Adria zum schwarzen Drin (Sarajevo: Kajon, 1908); Franz Baron Nopcsa published his travel account Aus Sala und Klementi: Albanische 
the Albanians at the "Urania," a Viennese institute for popular scientific education, discussing their origins and "psyche" and depicting the country as an ideal new field for the anthropological sciences.

As with any other European people, Germans, Greeks, Slavs, and Italians, the origin of the Albanians stretches far back into prehistoric darkness. It can only be explored with the aid of ethnology, anthropology, archaeology, and comparative linguistics. From this point of view, the seclusion to which Albania was condemned under Turkish rule had advantages and drawbacks. Ethnology and anthropology have profited, comparative linguistics has suffered to a minor degree. Positive damage can be recorded for the "science of the spade." The author of these lines was one of the few who have tried in the last years to unearth parts of the so-called artificially preserved treasures for ethnology and other sciences. ${ }^{34}$

Nopcsa called Albanians "Europe's armed children" and advised those dealing with them that the "wild mountaineers" were to be "handled delicately, like chinaware. With rough brutal energy and brute violence, one can achieve short-term quasi-success, but the reaction can be expected sooner or later." 35 Demonstrations of decisiveness, a potential for violence, and intolerance of personal affront were, in his opinion, indispensable for acceptance in local culture and were best symbolized by the display of a sizeable firearm. His cover included a "going native" act based not only on fluency in Albanian dialects and knowledge of local dress, but also on his capacity and willingness to fight. His local partner Steinmetz also prized a Browning pistol as a means of ensuring respect. ${ }^{36}$ Nopcsa was not deterred by attempts on his life, apparently regarding them as a sign of his social acceptance. Traveling on the periphery of the Ottoman Empire had never been particularly safe or easy, and Ottoman officials were not fond of foreigners doing research in their border areas, in part because their own authority in the region was limited. Under the circumstances, weapons and disguises seemed advisable.

Nopcsa did not publish his material in monographic form until after the war. His interest in Albania was not restricted to science; he repeatedly offered his knowledge to political decision makers in Vienna. The "Urania" lecture, for example, especially the section on the Albanian psyche, was intended to educate the Foreign Minister, Leopold Graf Berchtold. But Nopcsa's enthusi-

Wanderungen (Sarajevo: Kajon, 1910), but also contributed to the official periodical of the Landesmuseum: Wissenschaftliche Mitteilungen aus Bosnien und Herzegovina; another contributor to Patsch's series was the Albanian nobleman Ekrem Bei Vlora, Aus Berat und vom Tomor: Tagebuchblätter (Sarajevo: Kajon, 1911); and during the world war the Albanologist Maximilian Lambertz, Die Volkspoesie der Albaner: Eine einführende Studie (Sarajevo: Studnicka, 1917).

Franz Baron Nopcsa, "Die Albaner," Urania 1/2 (1913): 2.

Marchetti, "Scientists with Guns," 165-190. 
asm for the Albanian cause met with strong resistance among diplomats and politicians in Vienna. His interest in the corridors of power waned in 1913, when his plan to become king of the newly independent country caused only stifled amusement in Viennese diplomatic circles. ${ }^{37}$

\section{Ethnographic Warfare}

The assassination of Franz Ferdinand by a separatist in Sarajevo-with a Browning pistol-became the spark that ignited the powder keg of Europe. But the Balkans, whose post-Ottoman ethnic heterogeneity and violent nationbuilding processes were already perceived as sources of political turbulence, played only a minor part in the war.

In 1916, World War I was at its peak. The multiethnic Austro-Hungarian Empire had struck down its archenemy Serbia, but only with substantial assistance from its German ally. To distract from their own weak performance, imperial forces chased the collapsing Serbian army down the Balkan Peninsula, conquering Montenegro and occupying northern parts of neutral Albania on the way. ${ }^{38}$ Bulgarian forces held the eastern part of Albanian-populated territory, while the southern part was occupied by French and Italian troops. The invading armies were slowed by flooding and the lack of roads and bridges and weakened by the subtropical climate's heavy winter rains and malarial summer swamps. The local population was not overtly hostile, but, in the eyes of the occupiers, the Albanians remained wild and unreliable, lacking a sense of national unity. The occupation was experienced as a "colonial campaign." ${ }^{9}$

Decisive fighting during the occupation, as well as the pursuit of the Serbian army down the peninsula, was led by a pro-Habsburg volunteer corps. Two of its leaders were Nopcsa and Steinmetz. Soon after the forces occupied Albania and installed a military administration, Nopcsa was expelled from the country; army officials suspected him of following his own agenda. ${ }^{40} \mathrm{He}$ shared this

37 Robel, Franz Baron Nopcsa und Albanien, 111-112.

38 Manfried Rauchensteiner, Der Tod des Doppeladlers: Österreich-Ungarn und der Erste Weltkrieg (Graz: Styria, 1993), 319-321.

39

Österreichisches Bundesministerium für Heerwesen und vom Kriegsarchiv, ed., Österreich-Ungarns letzter Krieg, vol. 4, Das Kriegsjahr 1916, Part 1: Die Ereignisse Jänner bis Ende Juli (Vienna: Verlag der Militärwissenschaftlichen Mitteilungen, 1933), 80. The authors of this officious war account put the term in quotation marks themselves.

40 Kriegsarchiv-Wien, AOK-OpAbt/B-Gruppe/1916/Nr. 24112, 22 April 1916. Nopcsa spent the rest of the war spying on Serbian infiltration in Rumania, where his family's estate was situated. As a result of the war, these possessions were lost. Nopcsa never returned to Albania and committed suicide in 1933. 
fate with other experts on Albania, all of them, vis-à-vis the military, victims of mutual antipathy. Military men disliked the experts' know-it-all manner, along with their insubordination and "Orientalized" appearance.

While the Empire's political and military leaders debated the goals of the war, their subordinates on the ground in Albania were at odds about the country's future. Diplomats wanting Albania to become a quasi-independent Austrian satellite encouraged Albanian nationalism, while the military saw Albania as the spoils of war and had clear colonial ambitions. The XIXth Army Corps installed a military administration and adopted various measures to pacify and govern the country. To stem the chronic violence, they proclaimed a general besa, a temporary moratorium on family feuds. ${ }^{41}$ Later, the administration tried to end blood revenge once and for all by installing commissions of reconciliation. ${ }^{42}$ The Habsburg High Command ordered the creation of a militia, with divisions based on different tribes. Given the country's peculiarities, conscription was shelved in favor of volunteer enlistment. ${ }^{43}$ Generally, Albanian volunteers were assigned to Bosnian units and sent to the front lines. The military saw its discipline as part of a civilizing mission. It would help to

put under surveillance the larger part of the population, which may be fit for military service but is actually always lazing around, and is therefore easily engaged in suspicious activities, and to get an overview of the military potential of the country and gain some positive influence on the population. ${ }^{44}$

41 In the ethnological literature on Albanian feuding, "besa" is translated as "holy promise" and defined as oath for reconciliation, the reconciliation itself, and the holy obligation of the ritual itself. See Stefanie SchwandnerSievers, "Humiliation and Reconciliation in Northern Albania: The Logics of Feuding in Symbolic and Diachronic Perspectives," in Dynamics of Violence: Processes of Escalation and De-escalation in Violent Group Conflicts, ed. Georg Elwert (Berlin: Duncker \& Humblot, 1999), 133-152. The k.u.k. authorities interpreted the word without its ritual "sacredness," ascribing to it a more general temporal public peace. Reconciliation was carried out with adequate bureaucratic formalism: Kriegsarchiv-Wien. XIX.Korps.1916/581/I-XXXVIII.

42 Mariano San Nicolo, Die Verwaltung Albaniens durch die k.u.k. österreichischungarischen Truppen in den ersten zwei Jahren der Besetzung des Landes an der Hand der ergangenen Befehle (Vienna: Druckerei des k.u.k. Kriegsministeriums, 1918).

43 Armeeoberkommando: Albanesen-Ausbildung, 13 April 1916, Kriegsarchiv, AOK-OpAbt/B-Gruppe/1916/Nr. 23366.

44 XIX Korpskmdo Op. Nr. 734/19, 26 March 1916, Albanesen Ausbildung Trollmann, in Armeeoberkommando: Albanesen-Ausbildung, 13 April 1916, Kriegsarchiv, AOK-OpAbt/B-Gruppe/1916/Nr. 23366. While k.u.k. diplomats advanced the creation of purely Albanian units and saw them as a precursor for a later national Albanian army, the military only reluctantly provided its heraldic competence to design adequate flags, showing the Albanian eagle 
To aid in organizing the tribal militia, the High Command put out a booklet entitled Tribal Structure, Norms, and Customs of the Albanians, ${ }^{45}$ extracted from a manuscript by the missionary Mihačević, who was now prior of the Sarajevo district's Franciscans. In large part, it had been translated and published in 1913 in Prague. ${ }^{46}$ It portrayed the rural Albanian population as separated into distinct clans, each of which could be traced back to a common ancestor, listing their territories in both Albania and Macedonia along with Catholic dioceses and parishes. The booklet portrayed the Albanian as a patriarchal tribesman, eternally armed and ready for a fight. His choleric temper and explosive violence is bound by a code of honor including blood revenge, besa, and hospitality. Mihačević described Albanians as heroic fighters, valued by the Ottomans and attaining to high ranks in their army, but called ambush and sniping their preferred tactics.

Turning these "tribal warriors" into disciplined soldiers was no easy task for Austrian officers, especially when they were also instructed to respect their costumes and psyches. Drill instructors were forbidden to use corporal punishment on Albanian volunteers; such an act would "force" the victim to take blood revenge. ${ }^{47}$ The dissonance between such representations and officers' actual experiences persisted throughout the occupation, causing lengthy disputes between liberal diplomats and military officers who urged a less sympathetic treatment of the volunteers, until the formations were dissolved in early $1918 .^{48}$

\section{Warlike Ethnography}

While the Sarajevo Institute could resort to a network of informants on site, and privileged mavericks were themselves capable of carrying their knowledge to the metropole, Viennese scholars needed a new arrangement to access the periphery.

on red ground, for it denied the Albanians sufficient patriotism. Kriegsarchiv Wien. AOK-OpAbt/B-Gruppe/1916/Nr. 25205, 20 May 1916.

45 Fra Lovro Mihačević, "Stammesgliederung, Sitten und Gebräuche der Albaner, Armeeoberkommando (Broschüre)," in KA, Zu K.-Nr. 23759.

46 Idem, Durch Albanien: Reiseeindrücke, trans. from the Croatian by Otto Slavik (Prague: Bonifatius-Buchdruckerei, 1913).

47 Allgemeine Direktiven für die Ausbildung der Albaner. Kriegsarchiv, AOKOpAbt/B-Gruppe/1916/Nr. 24336.

48 Stephan GrafBurian-Rajecz, "Auflösung der Albanerformationen," 17 September 1918, Hofarchiv, Diplomatie und Außenpolitik 1848-1918, GKA KsA Skutari, K 17 Verwaltung 1916-1918, 690. 
Accordingly, on May 11, 1916, Dr. Franz Kidrić bought himself a gun. A Slavicist in the employment of the Imperial Library, exempt from military service, he was preparing to take part in a scholarly venture officially entitled "Expedition [for the study of] Arts, History, Ethnography, Archaeology, and Linguistics in the Imperial-and-Royal Occupied Zones in Serbia, Montenegro, and Albania, Commissioned by the Ministry of Education and the Imperial Academy of Sciences." ${ }^{\prime 9}$

The impetus for the interdisciplinary expedition came from a meeting in the Ministry of Education that had been called to address the issue of collections and libraries in the occupied Serbian capital of Belgrade. The collections were scientific booty and had to be disposed of in a scientific way. Against a backdrop of struggles to pacify Albania, the plan for a historical-ethnographic Balkan expedition emerged as a tangent to this discussion. Its official mission was to demonstrate the strong scientific interest and the Kulturmission of Austria-Hungary in the Balkans and to counter enemy propaganda. ${ }^{50}$

One of the participants in the initial meeting was Michael Haberlandt, who attended as a representative of the Imperial and Royal Central Commission for the Protection of Historic Monuments. His son Arthur was a freshly qualified private lecturer in ethnography and heir apparent to his father's career. He had enlisted voluntarily, serving in the fortress of Trebinje in southern Herzegovina, and was wounded twice. He was one of the first to be named as a potential member of the expedition and one of the few to remain on the list throughout the planning process. It is conceivable that beyond the younger Haberlandt's scholarly qualifications and interests, the chance to serve with less risk to life and limb had its share in his and his father's motivations. ${ }^{51}$

Plans for the expedition took shape quickly. Six scholars, all in their late twenties or early thirties, were appointed to travel to Montenegro, northern Albania,

49 "Kunsthistorisch-Archäologisch-Ethnographisch-Linguistische Balkanexpedition in den k.u.k. besetzten Balkangebieten, im Auftrag des k.k. Unterrichtsministeriums und der kaiserlichen Akademie der Wissenschaften in Wien." With the label "expedition," the journey gained a heavy symbolic valorization. As the typical mode of traveling scientific exploration, expeditions were the products of intricate alliances between intellectual and commercial elites and stood in the focus of public interest. They served as powerful ideational and ideological apparatuses through which European citizenries related themselves to other parts of the world. See Mary Louise Pratt, Imperial Eyes: Travel Writing and Transculturation (London: Routledge, 1993), 23.

50 Allgemeines Verwaltungsarchiv Wien. 02 Unterricht "Kunstwesen Ausland in genere," K. 3118. Nr. 2709. 26 January 1916.

51 The numerous letters of petition sent by Haberlandt senior in the name of the Association for Austrian Volkskunde, pleading for the exemption of Haberlandt junior from military service for varying reasons, support this perception. 
and Serbia from May 22 to August 12, 1916. They were: Arthur Haberlandt, ethnographer; the Slavicist Franz Kidrić; two archaeologists, Arnold Schober and Camillo Praschniker; the linguist and expert on Albanian dialects Maximillian Lambertz; and the art historian Ernst Buschbeck. Haberlandt, Buschbeck, and Praschniker were army officers, while the rest were civilians. Kidrić and Schober had been exempted from military service in order to teach, respectively, Russian language at the Oriental Institute and archaeology at the university. Lambertz was considered unfit for service due to myopia.

As no one could travel to the Balkans unarmed, the civilians received permission to carry weapons. Kidrić also sought permission to wear a kind of uniform. He eventually received a grant to buy a sword and supplement a grey raincoat with some elements of a uniform so that he could travel under the guise of a military officer. ${ }^{52}$ While the civilians braced for their contribution to the war effort by dressing up as soldiers, the military men seemed to appreciate their new posting as a chance to avoid the lethal trenches of the front lines. At the head of the expedition was Buschbeck, the highest ranking officer.

The established academics, mentors to the young scientists, had apparently been candid about the enterprise's primarily scientific aims, but political and strategic goals were in evidence from the start. The expedition's participants were ordered to fulfill military requests "as far as possible to allow them to comply with their time budget and the aims of their scientific research." ${ }^{3}$ The military mainly sought expert assessment of the economic situation in the occupied regions. In an eleven-point list, it requested attention to aspects of the agrarian sector, infrastructure, natural resources and raw materials, social and cultural matters, and potential colonization and assimilation of the territory and its population. ${ }^{54}$

An official order permitted the group the use of military transportation and support and advised the occupation forces to assist the scholars in every way possible. From Vienna, the expedition traveled by train via Budapest to Sarajevo. Arthur Haberlandt began his ethnographic work on the way from the military harbor of Cattaro (Kotor) to Montenegro's capital at the time, Centinje. The expedition followed the military campaign's route over the Lovćen pass, where the decisive battle over Montenegro had been fought. From Podgorica, they crossed Lake Skutari and entered Albania. Skutari (Shkodra) became the expedition's base. ${ }^{55}$ From there, the journey continued via Kruja,

52 Hofarchiv-Wien, Oberstkämmerer-Amt, R.56,55/ No. 3092. 12 November 1916.

53 Rundschreiben an alle Teilnehmer wissenschaftlicher Expeditionen nach Serbien, Montenegro und Albanien. 1916/5, ÖAW, Balkankommission, K3 H10.

54 Ibid.

55 The k.u.k. administration tried to switch from the use of Italian spelling for town names to Albanian spelling. This attempt to eliminate Italian influence 
Tirana, and Elbasan southward as far as the Shkumbi River, which divides northern and southern Albania. Following the Shkumbi upstream, the expedition reached its headwaters, then turned northward back to Skutari. Travel was restricted to areas occupied by Austria-Hungary, in part due to Bulgaria's refusal to permit access to Bulgarian-occupied parts of western Albanian territory. From Skutari, Haberlandt and Buschbeck proceeded to cross the northern range into Kosovo on foot, reaching Belgrade by train. Schober returned to Vienna for the new academic semester, while Lambertz stayed on to study several local tribes' dialects. Kidrić and Praschniker were hospitalized for malaria and dysentery. ${ }^{56}$

The expedition's premature end surprised no one. The differences in scholarly objectives and methods that affect any collective scientific pursuit, conflicting opinions as to which sites were of interest, and divergent approaches to the population led the group to disband. While the linguist Lambertz, the most independent due to his fluent Albanian, hardly mentioned his colleagues in his report, Arthur Haberlandt praised the project's interdisciplinarity and was conscious of benefiting from military support. As he pointed out, many areas were accessible only because of the occupation. They included the interiors of Muslim homes; taking pictures there had previously been impossible. ${ }^{57}$ Albanian recruits were available for measurement and photography with methods advanced by Rudolf Pöch for use in prisoner-of-war (POW) camps. ${ }^{58}$

The material encountered by the expedition was sorted into various categories. Language, spoken or written, served as linguistic and historical evidence; Kidrić collected recent war-related publications for the war collection

was never fully implemented and, consequently, Italian names with Albanian names in brackets were used.

Arthur Haberlandt, "Bericht über die ethnographischen Arbeiten im Rahmen der historisch-ethnographischen Balkanexpedition," in Mitteilungen der Geographischen Gesellschaft in Wien 59 (1916): 736-742; Maximilian Lambertz, Bericht über meine linguistischen Studien in Albanien von Mitte Mai bis Ende August 1916 (Vienna: Verlag Kaiserl. Akademie der Wissenschaften, Philosophischhistorische Klasse, 1916); Camillo Praschniker and Arnold Schober, Archäologische Forschungen in Albanien und Montenegro (Vienna: Hölder, 1919); Ernst Buschbeck, "Vorläufiger Bericht über die Balkanexpedition im Sommer 1916," Mitteilungen der k.k. Zentral-Kommission für Denkmalpflege 16 (1918): 1-13; Hofarchiv Wien, Oberstkämmerer-Amt B/K 908/II/1916, R. 56 Nr. 2660, 1916/8/1.

57 Haberlandt, "Bericht über die ethnographischen Arbeiten."

58 Haberlandt published the results of these anthropological measurements together with Viktor Lebzelter, who added material of Albanians he measured in Austrian prisoner-of-war (POW) camps. Arthur Haberlandt and Viktor Lebzelter, "Zur physischen Anthropologie der Albanesen," Archiv für Anthropologie 17 (1919): 123-154. See also the articles by Margit Berner and Britta Lange in this volume. 
of the Royal Library and unearthed ancient Orthodox religious manuscripts from abandoned monasteries. The archaeologists discovered classical statuary and surveyed medieval towns and Roman fortresses. Beyond his ethnological data, Haberlandt also collected products of contemporary craftsmanship including pottery and elements of traditional costume.

But the expedition's mission was not to plunder in the name of science. The official instructions had stipulated that nothing may be carried away that the native population might regard as valuable, at least not for the moment. Not that all the researchers obeyed these instructions: Haberlandt carried home no fewer than 120 items, most of them bought at the bazaars of Skutari (Shkodra) and Üsküb (Skoplje). While Liebhaberei-collecting as a hobby or, better, for sentimental reasons-was an adequate excuse for officials back home, Haberlandt's reasoning was professional: His approach to ethnography was centered on things. Museum-based comparative scholarship needed objects and could not work with recorded evidence alone. Coming home emptyhanded would have made proper scientific inquiry impossible.

The expedition's primary mission was explicitly scientific, with no military purpose. But as its members interacted with the occupation, various paths eventually led them away from scientific neutrality. Some members became directly involved in the politics of occupation and the operations of military repression. Lambertz, having left his colleagues in order to roam the northern Albanian highlands, attached himself to an Austro-Hungarian battalion under the command of Oberstleutnant Gustav Broser, whom he had met in the village of Lurja Eper. As Broser was assigned to hold trials in Lurja and the neighboring Ksela tribal area, Lambertz was asked to assist with his knowledge of the native language. He submitted a report summarizing his duty:

What I experienced in my ten-day collaboration with the 19th battalion, in arduous cooperation with its pleasant officers in this uncomfortable corner of Albania, belongs more to the political history of Albania in these stormy times than in a scientific report of a learned society. Suffice it to say that we forcefully had to call it to the attention of the Mohammedan Lurjas, as well as to the in no way better Catholic Kselas, that the "good old" Albanian times were over, and that Central European civilization in the form of the Austro-Hungarian Army had permitted itself to knock on their doors, which were closed to cultural and ethical appeals. ${ }^{59}$

The visit from Central European civilization, as Lambertz failed to mention in his report, left around forty-four Albanian villagers dead. ${ }^{60}$ Lieutenant Colonel Broser had led a punitive military expedition in response to an assault

59 Lambertz, Bericht über meine linguistischen Studien in Albanien, 26.

60 August Ritter von Kral, 4 Oktober 1916, "Verstimmung der Albaner," in Anträge auf Änderung der Militärverwaltung in Albanien, Auszug aus einer 
on a mountain patrol that had killed two soldiers. Villages were searched for weapons, hostages were taken, and suspects executed. For the Counselor of the Foreign Ministry to the Military Administration in Albania, August Ritter von Kral, the "affaire Lurja" was proof that his military counterparts were acting without regard to the monarchy's relations to Albania. He charged the military not only with lacking understanding and goodwill, but being unwilling even to try to understand the character of the country's population. Kral alleged that Broser's repressions produced more than the officially stated forty-four dead, and that the imperial forces were accompanied by a band of Mirdite tribal warriors under the leadership of Kapetan Marka Dijon who allowed them to rob, loot, and murder. ${ }^{61}$ Kral's attack was aimed at the head of the general staff in Albania, Colonel Lustig, whose orders he called "demonic and dreadful." Lustig's conduct was based, he wrote, on the assumption that the Albanians were an inferior and despicable race to be tormented with impunity and crushed like worms. ${ }^{62}$

The disdain that civil and diplomatic personnel involved in the administration of occupied Albania felt for the military was mutual. While diplomacy followed a policy of nation-building, the military denied the Albanians the character of a nation, preferring to depict them as "partitioned into countless tribes, feuding with each other, situated on the lowest level of culture." Only a full integration of the occupied territory into the monarchy's realm and its civilizing dominion over the mountain tribes could secure the border region for Austria-Hungary. ${ }^{63}$ The various tribal policies can be seen as part of this strategy.

For the scientists, now considered experts on the region because they had toured it, the situation held various opportunities. Only three of them returned to their previous occupations while the war lasted: Schober kept his position at the Archaeological Institute in Vienna, and Kidrić rejoined the Imperial Library, while Buschbeck alone returned permanently to his military post. He advanced to become a staff officer in the Orientkorps and was involved in partisan fighting in eastern Albania up to the end of the war. Lambertz, having collaborated in the military's tribal strategy, changed sides to join the diplomatic project of nation-building. Kral had established a Literary Commission

Note des Außenministeriums, Kriegsarchiv, AOK-OpAbt/B-Gruppe/1916/K 510, Nr. 31667.

61 Ibid.

62 Idem, 3 August 1916, "Abberufung des Generalstabschefs Oberst Lustig," Hofarchiv, Diplomatie und Außenpolitik 1848-1918 GKA KsA Skutari, K 21 Nr. 804.

63 Franz Conrad von Hötzendorf, 20 April 1916, "Alleruntertänigster Vortrag über Kriegsziele der österreichisch-ungarischen Monarchie," Kriegsarchiv, AOK-OpAbt/B-Gruppe/1916/Nr. 24055. 
of Albanian intellectuals, including the priest and poet Gjergi Fishta, author of the epos of Albanian national struggle Lahuta e Malcis, and the linguist Gjergi Pekmezi, to elaborate on the question of an official Albanian alphabet and to develop textbooks for Albanian schools. Lambertz became secretary of the Commission and played a decisive role in its progress. ${ }^{64}$ Other expedition participants were assigned to the Orient Department of the War Ministry, installed in early 1917 to secure trade routes and supply lines with the Ottoman ally and other Near-Eastern countries. ${ }^{65}$ The Ministry returned the archaeologist Praschniker to Albania under orders to protect antique monuments and artefacts put at risk by warfare. ${ }^{66}$ The craving of imperial soldiers for souvenirs was among the more urgent dangers; Praschniker's mission included collecting and securing antiquities and making provisions for a museum. Kral had been thinking about the prospect of a national museum in Albania ever since he had toured the country with Patsch, starting from Sarajevo in November of $1917 .{ }^{67}$

The question of borders was another source of discord within the occupation regime, and redemption from the deadlock was to be provided by a scientific expert. After the occupation, imperial forces had turned the border between Montenegro and Albania into a demarcation line between two military governmental units. While Montenegro as conquered enemy territory was ruled by a Generalgouvernement, Albania was formally a neutral occupied country, administered by the XIXth Army Corps. Thus, the demarcation of the London Conference in 1912 was maintained, even though it contradicted the position that the Habsburg monarchy had taken during the proceedings. The ostensibly trivial administrative decision had severe local consequences. It cordoned off parts of the Gruda and Hoti tribes from their traditional markets, and Malsor shepherds farther east found trails to their pastures cut off. While diplomacy struggled to solve the problems, which were affecting Austria-Hungary's local prestige, the military insisted that the question of borders could only be solved in conjunction with that of the future status of the whole country. ${ }^{68}$ Arthur

64 August Ritter von Kral, 21 Oktober 1917, Albanische literarische Kommission, Hofarchiv, Diplomatie und Außenpolitik 1848-1918 GKA KsA Skutari, K 21, Konvolut 18, Nr. 753.

65 Orientabteilung, "Tätigkeitsbericht der Orientabteilung des k.u.k. Kriegsministeriums über das Jahr 1917," Kriegsarchiv, Kriegsministerium, Internakten, Karton 128, Nr. 4162.

66 Ibid.

67 Albanisches Nationalmuseum, 8 April 1918, Hofarchiv, Diplomatie und Außenpolitik 1848-1918 GKA KsA Skutari, K 21 Nr. 1815.

68 August Ritter von Kral, 6 May 1918, "Frage der Einverleibung von Gruda und Hoti in Albanien," Hofarchiv, Diplomatie und Außenpolitik 1848-1918 GKA KsA Skutari, K 20 Akt 5 Nr. 382. 
Haberlandt, who had returned to his artillery unit, was assigned to the Orient Department in early 1918 and charged with traveling as a scientific delegate into the "Slavic-Albanian borderlands." The plan was strongly supported by the Foreign Ministry. ${ }^{69}$

\section{Using the War}

Arthur Haberlandt's solo expedition never took place. Examining the interconnections of war and science, the historian Mitchell Ash points out that instrumentalization of scholarship by the military is a mutual effort. Research autonomy appears to be a matter of bargaining; to gain access to resources the military can offer, especially in times of war, the scientist must have something to exchange-not necessarily a product, more often a project or program.

The Orient Department, apart from promoting the Empire's war economy by organizing trade and supply from the southeast, was engaged in the economic and cultural development of the occupied Balkan territories. ${ }^{70}$ Part of its cultural mission was to support the collection of ethnographic objects for the Kaiser Karl Museum für österreichische Volkskunde. The Haberlandts were commissioned with staging a public exhibition, which opened under the title "On the Volkskunde of the Occupied Balkan Territories" in the ballroom of the University of Vienna in January, $1918 .^{71}$ They had already designed a display to present products of home industry from the occupied region in the Museum for Arts and Industry in October, 1916. While the first exhibition had displayed mostly objects collected before the war updated with photos from the expedition, the second show incorporated Arthur Haberlandts's Liebhaberstücke-his private collection-and other collections and portrayals made during the occupation, such as the work of the artist Leopold Forstner. ${ }^{72}$ Despite his duties at the Orient Department, Haberlandt found time to promote the relocation of the Volkskunde Museum from the stock exchange building to its new (and still

69 Kommandierung des Lt. d. Res Dr. Artur Haberlandt G.A.R.8 zur O.A. 1918/4/26, Kriegsarchiv, KM/Orientabteilung, Nr. 9366.

70 Orientabteilung, "Tätigkeitsbericht der Orientabteilung des k.u.k. Kriegsministeriums über das Jahr 1917," Kriegsarchiv, Kriegsministerium, Internakten, Karton 128, Nr. 4162.

71 See report in Zeitschrift für österreichische Volkskunde 21-22 (1915-1916): 201-202; "Die Balkanausstellung in der Universität," Neues Wiener Tagblatt, January 8, 1918.

72 Forstner traveled Albania in 1917 on behalf of the Imperial Military Museum; he collected and painted also for the Museum of Austrian Volkskunde. See Leopold Forstner, "Studien in Albanien und Mazedonien," Kunst und Kunsthandwerk 21 (1918): 8-10. 
current) home in the Palais Schönborn. The relocation was eventually carried out, with logistical support from the military, in 1918.

The Haberlandts also attempted to formalize a program of ethnographic contribution to the war effort. By the time the war ended, Arthur Haberlandt had written two monographs. The first, a detailed account of the expedition's findings, was published in 1917 as a special issue of the journal Volkskunde. After a lengthy passage on Balkan culture, he offered practical advice: The region possessed "in the modern sense inferior, but sufficiently developed economic and cultural bases that must be treated as autonomous and selfcentred economic entities, and not as virgin soil for colonial engagement by the West."73 Determination and a commitment of material support would be needed to overcome the natives' primitive, individualistic, and unproductive self-assertiveness. On a footing of self-confident power, imperial will might unite the fragmented people and lead them to higher stages of organization and culture, while education and literacy would accustom Montenegrins and Albanians to regular labor, integrating them into European civilization. ${ }^{74}$ In a memorandum to the War Ministry in 1917, the Haberlandts offered additional advice, proposing short essays for textbooks, pictures, and movies to help convey knowledge of the Balkan Peninsula to military personnel. ${ }^{75}$ The scientists even attempted to involve the military in collecting objects: The memo explained how to deal with the volkskundlicher Besitz [folkloric possessions] of occupied peoples, indicating that objects should not be misappropriated. Carpets and embroidery, even small wooden objects like spoons or forms for cheese, should be regarded as valuable both in the material sense as products of a domestic industry worthy of protection and as potential national symbols. ${ }^{76}$ If found abandoned, such objects should be collected and delivered to the museum in Vienna. An officer with appropriate expertise should be assigned to catalog the objects, most likely Arthur Haberlandt. Ethnographic research would have a positive local propagandistic effect by demonstrating the Habsburg rulers' concern for the cultures of their subjects.

73 Arthur Haberlandt, Kulturwissenschaftliche Beiträge zur Volkskunde von Montenegro, Albanien und Serbien: Ergebnisse einer Forschungsreise in den von den k.u.k. Truppen besetzten Gebieten Sommer 1916, trans. by Christian Marchetti (Vienna: Verein für österreichische Volkskunde, 1917), 167.

74 Ibid; The second monograph, a luxuriously printed folio volume with numerous pictures and single-spaced text, dealt with Balkan folk art and was published in 1919, immediately following the Austro-Hungarian defeat in the war.

75 "Zur wissenschaftlichen Erforschung der besetzten Balkangebiete," Zeitschrift für österreichische Volkskunde 23 (1917): 91-92.

76 "Obsorge für die Volksdenkmäler in den Kriegsgebieten," Zeitschrift für österreichische Volkskunde 23 (1917): 132-133. 
The museum would become the scholarly center of Balkan studies after the expected victory. ${ }^{77}$

Perhaps the Haberlandts were not merely selfish in preferring museum work to mediating border disputes in the Balkans. Ethnographic interests and activities were presented as having positive propagandistic and socially mobilizing effects. The elder Haberlandt insisted that Volkskunde could supply a scientifically ascertained canon of indisputable facts to counter any nationalistic argument. It could provide a clear picture of the ethnographic distribution of people and of their actual condition as well as the multiple cultural interrelations of the Volksstämme of the Empire. "Idiosyncrasy in all that is small and inward, commonality in all that is big, and united loyalty always and forever against the outside - this is the Austrian motto!"78

In January 1918, Woodrow Wilson declared his Fourteen Points for a postwar world, invoking the principle of national self-determination in proclaiming that "the peoples of Austria-Hungary, whose place among the nations we wish to see safeguarded and assured, should be accorded the freest opportunity of autonomous development." Arthur Haberlandt sketched Austrian Volkskunde's response to such claims:

What are peoples, how is their life, their existence made up, that they are now supposed to determine themselves, and what is the worth of the word "determine" against the unalterably given geographical conditions and the historically grown actual states? ${ }^{79}$

Arthur Haberlandt believed that neither constitutional law nor science could provide a consistent definition of a Volk [people]. ${ }^{80}$ Consequently, in his definitions, Volksstamm [tribe] and Volk were defined by "objective" common descent, language and culture. A Nation was a political entity, exemplified by the Swiss and American multiethnic nations. In the face of the highly differentiated and complex situation of the peoples of Europe and its multitude of contested

77 Archiv des österreichischen Vereins für Volkskunde Wien, Karton 3, Faszikel: Sitzungsprotokolle, "Protokoll der Sitzung des Unterausschusses für die Balkan-Abteilung des Kaiser Karl Museums, 7.3.1918."

Michael Haberlandt, "Nationalitätenstaat und Volkskunde," Österreichische Rundschau 53, no. 1 (1917).

79 Arthur Haberlandt, G. Freytags Völkerkarte von Europa (Vienna: G. Freytag \& Berndt Kartogr. Anstalt, 1918) (with a commentarial text).

80 Haberlandt expounded the problems of the use of language as an index of nationality as it was used by k.u.k. statistics. An interesting account of the role of the concepts of "Nation," "Volk," and "Volksstamm" in AustroHungarian constitutional law and judicial praxis is given by Emil Brix, Die Umgangssprachen in Altösterreich zwischen Agitation und Assimilation (Vienna: Böhlau, 1982), 36-66. 
borders, whether of language or culture, Haberlandt praised the Swiss paradigm as a state-organized community of "tribes." A multilingual state could free people from the narrow cage of language and further the development of "higher European culture." One can infer from these statements a distinct claim for German leadership, that is, a desire to install German as the lingua franca of the empire and its science. Such claims were never explicitly formulated. The hegemony of "higher" German culture, which would lead Slavic and Balkan "folk cultures" up the ladder of "European culture," was increasingly alluded to, but the claim was still tacitly based in a liberal paradigm.

From early 1918 on, leaders of the Empire's most influential political bodies engaged in controversial discussions of ethnographic questions, such as whether there is a South-Slavic nation. But soon a reality indifferent to such "facts" took over. ${ }^{81}$

\section{Losing the War}

Neither the Haberlandt nor the Habsburg dynasty could avert the dismemberment of the Empire after its defeat. For the scientists, the end of the war was more or less concomitant with the end of the liberal paradigm. As late as November of 1916, the Volkskunde Museum had been praised as "an outstanding monument to the Austrian Völkerschaften [peoples] and to the glorious unity of all Austrian Völkerstämme [tribes] in the war." ${ }^{22}$ Yet as early as March 1919, in a memorandum to the State Department of Education, the Haberlandts praised their museum's collection as being centered on German-speaking Austria and "depicting the autochthonous folk culture of the German Alps and Germans in the Sudetenland in all their expressions in an instructive display." In the eastern European collections, it was no longer underlying universal principles that surfaced, but instead "the broad cultural insemination and influence of German culture." ${ }^{83}$ The displays had not changed; the objects were simply as apt to construct nationally homogeneous imagined communities as to argue

81 Holm Sundhaussen, "Von der Multiethnizität zum Nationalstaat: Der Zerfall 'Kakaniens' und die staatliche Neuordnung im Donauraum am Ende des Ersten Weltkrieges," in 1917-1918 als Epochengrenze?, ed. idem (Wiesbaden: Harrassowitz, 2000), 79-100.

82 Präsidium des Vereines für Österreichische Volkskunde and das k.k. Ministerium für Kultus und Unterricht um Bewilligung von Subventionen, 10 November 1919, AVA 02 Unterricht, Museum für österreichische Volkskunde, Nr. 36016.

83 "Denkschrift über das Museum für Volkskunde Wien, AVA 02 Unterricht," 27 March 1919, Kaiser Karl Museum für Volkskunde, Nr. 12420. 
for the unity of the European peoples. ${ }^{84}$ The Haberlandts continued to publish on European folk culture through the late 1920s ${ }^{85}$ Arthur Haberlandt lectured Wehrmacht soldiers in occupied Belgrade on the folk art of the Balkans. ${ }^{86}$

Other experts executed a similar about-face. Patsch, who during the war had struggled to claim a piece of the war-induced scientific boom for his Balkan Institute (apparently, e.g., planting the article quoted at the beginning of this chapter), was forced to leave Sarajevo and set up a new Balkan Institute in Vienna in 1919. In 1924, he was invited by the Albanian government to design an Albanian national museum in Tirana. Drawing on his experience in Sarajevo, both positive and negative, he insisted it be not a Landesmuseum [country museum] but a national museum, displaying all of Albanian culture whether inside or outside the state's political borders. ${ }^{87}$

During World War I, Viennese Volkskunde basked in attention from state institutions as never before, helping to legitimize a multiethnic empire that would transfer its internal colonialism to new annexations. By the time ethnography toured Albania in an occupier's uniform, the country's culture was less a model for heroic posturing than an asset for appropriation by a German-Habsburg sense of cultural mission. As official policy, the international and subnational approach of Austro-Hungarian Volkskunde vanished with the Empire. But conserved for posterity in collections and accounts, multiethnic Volkskunde, continued-or continues-to underpin political aims even as circumstances change.

84 Johler, "Das ethnische als Forschungskonzept," 88. But also Albanian folklore scholarship under Communism could cite Franz Baron Nopcsa's and Arthur Haberlandt's works: Pirro Thomo, "Les habitations a kulle en albanie," Ethnographie Albanaise 12 (1982): 5-27; Spiro Shkurti, "Essai de classification des Araires Albanais," Ethnographie Albanaise 12 (1982): 93-131; Aleksander Dhima, "Variations du type physique chez les habitants du district de librazhd," Ethnographie Albanaise 12 (1982): 251-285.

85 Michael and Arthur Haberlandt, Die Völker Europas und ihre volkstümliche Kultur (Stuttgart: Strecker und Schröder, 1928).

86 Herbert Nikitsch, Auf der Bühne früher Wissenschaft: Aus der Geschichte des Vereins für Volkskunde (1894-1945) (Vienna: Selbstverlag des Vereins für Volkskunde, 2006), 400.

87 Carl Patsch, "Albanisches Nationalmuseum-Vorschläge-Konzepte," Bay HstA, Südost-Institut Nachlass Carl Patsch, K 276 Wiederbelebung der Erforschung Albaniens. 